\title{
Strategic Change in a Firm: Multifarious aspects
}

\author{
Jacek Nowak ${ }^{*}$
}

\begin{abstract}
Objective - The purpose of this paper is to review the existing body of knowledge concerning strategic change from a perspective that envisions the importance of time. Therefore, the review of existing literature will fundamentally be based on the various views.

Methodology of research - First, the concept of time in strategic change. Secondly, time and strategic change activities. Lastly, time and strategic change agents. The perspectives upon which this paper will focus are related to the time-related components of strategic change that most scholars have for long neglected to investigate.

Result - The approach entailed in this review is bound to change the aspect of looking at the strategic change in terms of its processual dynamics. As such, the paper will focus on different aspects of strategic change that strive to achieve its intended purpose.

Originality/value - The substantive and scientific value of this study is expressed in the presentation of the topic taken from an unusual perspective, referring to a specific translation of the theory into research conclusions regarding strategic change from the point of a multifarious aspects view. The original approach is different from those presented so far, with a look, to a large extent, using the latest literature sources, taking into account the complexity of strategic change, integrated into a company's problems from the perspective of various aspects in the context of corporate strategy.
\end{abstract}

Keywords: strategic change, corporate strategy, business environment

\section{Introduction}

The modern world has become a dynamic place where constant change is inevitable. As such, in ever-changing environments, it is essential for organizations to remain competitive in the face of the changing global markets (Kunisch, Bartunek, Mueller, Huy, 2017, p. 1037). In view of this, strategic change manifests in organizations have become a crucial feature of their success. These manifests have become particularly significant to the strategy and management activities of the organization. In this consideration of the dynamic global market in which modern organizations exist, it is particularly important to note that strategic change is affected by the aspect of time (Bartunek, Woodman, 2015, p. 159). Scholars have for long researched on the issue of strategic change while evading the issue of time that is pertinent to the change itself.

\footnotetext{
* dr inż. Jacek Nowak, Uniwersytet Ekonomiczny w Katowicach, ul. 1 Maja 50, 40-287 Katowice, e-mail: j.nowak@ ue.katowice.pl.
} 


\section{Theoretical Framework}

The most re-occurring event in the global market of the $21^{\text {st }}$ century is undoubtedly mergers and acquisitions. Over the past two decades, we have witnessed many companies merging together or others being an acquisition by other companies (Ellis et al., 2011, p. 1261). Research has however focused on the benefits of the mergers and acquisitions based on the reasons for undertaking the said activity in the first place. However, there is a lack of research on the post-deal consequence of those companies which are in a competitive business environment. One study shows that time is a great factor in merger and acquisitions as time plays an important role of depicting whether the decision made was beneficial or rather negatively impacting the business prospects of the given firms or organizations. Recent research depicts that most of the mergers and acquisitions tend to have compounding negative effects on the success of organizations and their employees alike. The negative consequences of the actions of the involved organizations are felt after a significant time which stands to prove that the reasons for making such drastic decisions were not applicable or agreeable in a given economy or business environment.

On the matter of acquisitions, there are various factors that have been noticed to be crucial to the resulting performance of the involved organizations in a dynamic market. Ellis, Reus, Lamont, and Ranft (2011) conducted a study to determine whether the experience of a firm in making different sizes of transfers over time had a significant effect on the performance of the resulting organization (p. 1262). The findings of their study indicated that the companies that had previous experience in making small acquisitions resulted in lower performance than those that had experience in making larger acquisitions. The authors argue that if the two organizations have a very large dissimilarity in size, there is a high potential for the acquisition transfer to result in the lower performance of the firm that initially expected. However, the study also shows that companies with small dissimilarities, which are between the target and bidding company, result in a more fruitful acquisition transfer than the former. Therefore, there seems to be a significant correlation between the size of the acquisition transfer made and the resulting performance of the involved organizations after the acquisition is completed.

Other authors, Heimeriks, Schijven and Gates (2012), present an argument on the basis that post-acquisition integration is a process that includes a variety of activities that span over several industrial or geographical settings (p. 720). Their argument is based on the findings of various researchers that showed that strategic change in organizations as defined by acquisitions and mergers have a very positive outcome in every two out of three M\&As. The successful nature of the acquisition or mergers is dependent on postacquisition integration which is the most significant aspect of this type of strategic change. However, most of the companies that do succeed in the post-acquisition stage undergo integration based on the aspects of codified routines witnessed in the patterns of successful companies. The author, however, adds that even though most companies exhibit success 
in integration during the post-acquisition period, at least one out of every three companies have been studied to exhibit some form of significant challenge that may hinder their strategic change goals and objectives. The matter of strategic change through M\&As is therefore highly dependent on the codified routines implemented to attain successful integration during the post-acquisition period.

\section{The multifariousity of strategic firm change aspects}

However, the organization that has failed is not to blame as there are a huge number of organizations that have benefited from making similar decisions in the past. More important is what makes an organization stand strong in the face of constant change in the dynamic markets of the world. It is prudent to note that a change can sometimes become difficult for most organizations, it is still crucial that organizations undergo a significant amount of change from time to time for the sake of staying competitive in an ever-changing market.

\subsection{Regularity of change}

Klarner and Raisch (2013) argue that the strategic changes in an organization take place in different ways which affect their performance in different ways (p. 169). The authors study the rhythms by which organizations change in order to remain competitive in the modern business environment. These changes were said to happen in punctuated, focused or temporarily switching rhythms which have a high significance on their resulting performance. The study indicated that the performance of companies that changed in a regular manner was higher than those that experienced a change in an irregular manner.

\subsection{Mental models}

Another study focuses on strategic change from the mental perspectives by bringing into focus the importance of mental models in the strategic process. Menon (2017), in his article, presents sound empirical evidence of the significance of mental models and how they affect the resulting performance of the strategic change that a given organization is undertaking (p. 188). The author argues that strategic interactions are affected by frameworks that are affected by various negative mental models. The article presents empirical evidence that alludes to the fact that the value based frameworks used for strategic change decisions in organizations are in violation of practical concerns. The article demonstrates that in any given strategic change scenario, there exists a certain value based framework.

However, the framework does not entirely consider the reality of the situation at hand as the complex realities are often transformed into inaccurate and incomplete mental models that often shape the nature of the resulting strategic change decisions. The findings of the article prove that in strategic interactions, real-life agents need to be included as a part of 
mental models as they end up informing a strategic change decision based on the truth of the situation at hand. Therefore, the use of analysis that differs highly from that obtained in reality will result in inappropriate strategic decisions that will be disappointing to the expected performance of the organization. The author goes on to share some aspects of the strategic mental models that ought to be considered in the light of the strategic change that is crucial to the performance of the organization in the future.

\subsection{Human cognitive behaviour}

According to Cummings and Nickerson (2017), the process of decision making concerning strategic change and strategic thinking is often affected by the various defects of human behaviour (p. 13144). These defects particularly allude to the weakness of human thinking and can be attributed to the cognitive level of the given decision makers. As such, the article presents a case that argues that the study of the brain, known as brain science has significantly shaped the making of strategic decisions by different individuals in an organization. Inter-level interactions lead to the formation of shared understanding and social consensus regarding the usefulness of ideas. By spreading useful ideas, a management team transfers them to the level of the team and the participant of the organization, thanks to which organizational behaviours are merged around the strategic goals of the company (Bratnicka, 2015, p. 137). In view of this, human cognitive behaviour has been named as one of the many crucial factors affecting the decision-making process of strategic decisions in the modern dynamic business environment.

The authors present various theoretical underpinnings that all seem to allude to the importance of human cognitive behaviour in the decision making process that significantly affects strategic changes in an organization. The authors depict that various aspects such as the knowledge-based view of a firm and the dynamic capabilities of strategic decisions often are the main contributors to the resulting strategic change decisions made in modern organizations. The article seems to focus on the fact that cognitive behavioural models that are important in informing the decision-making process in the strategic change of an organization.

The larger percentage of strategic change undertaken by many organizations in the modern world mostly involves moving to new markets in an effort to expand the operations of an organization to reach a global level. In such an intricate matter of expansion, Lee, Struben and Bingham (2017) argue that there is a list of things such companies should consider (p. 253). One of these is the condition upon which the actions of the market players are to include more collaboration than independence. It is prudent to note that most companies moving to new markets face the problem of the lack of familiarity with competitors and consumers in a given market. However, some markets may offer flexibility while others may not. For those markets that are flexible and easy to manoeuvre, companies opt to act independently and do not associate themselves with a formidable existing organization. However, in an instance that the markets prove to be fixed in response to new brands and 
products, companies enter into collaborative relationships with existing business establishments to enable them to successfully break through the market. A such, there are many intricate factors that organizations ought to look at before adjusting the scope of their business operations to include external markets that they have not previously ventured into.

As often witnessed in the state of business in the $21^{\text {st }}$ century, it is inevitable for an organization whose strategic change initiative involves a global capacity outlook to evade the aspect of diversity. Diversity comes naturally as a significant issue to be considered by business organizations operating in the $21^{\text {st }}$ century. It is undeniable that most organizations tend to focus on providing the same product in different markets. However, this method has proved to be a failure as it places most companies in business peril.

\subsection{Diversity}

According to Vidal and Mitchell (2017), diversity plays a significant role in determining a firm's performance (p. 132). Diversity nowadays translates to the human resource as well as the product catalogue. As such, companies need to consider the significant effects of diversity in the workplace environment that comes as a result of strategic change initiatives in a global perspective. Furthermore, product diversity is important for many things. First, different markets respond differently to the same product. Therefore, an organization ought to consider the preferences of consumers in different markets to enable a better response to the products that they offer. By diversifying their product portfolio, companies stand to benefit from increased sales through the reduced risk of product failure. Furthermore, it is easier to sell different products to different people according to their preferences than selling the same product to different people.

Previously studied authors in this paper have presented significant facts on the aspect of strategic change, the importance of time and other factors in aiding the process to successful completion. However, what they have lacked to mention is the aspect of environmental dynamism. To compete successfully, firms undergo strategic change on a regular basis. To change alludes to a critical reorganization of the objectives and goals and the activities carried out to accomplish the same. One of the most significant aspects of strategic change involves the alteration of organizational performance which can only be achieved by enabling a company to reach the point of dynamic capacity and capabilities. According to Girod and Whittington (2017), the more dynamic the change experienced by an organization, the more positive the outcome of the organization (p. 1127). As such, companies that experience limited configuration are geared to witness small changes in their performance.

\subsection{Business environment}

However, the outcome of each dynamic shift in capacity and capability is affected by the environment. One company may be successful in a given environment while the other 
company may fail by doing similar things in a different environment (Giron, Whittington, 2017). Therefore, different environments respond differently to change. As such, strategic change decision makers in a company ought to weigh the compatibility of the intended dynamic change in capacity and capabilities against environmental dynamism.

Another unique aspect of strategic change in organizations operating in the modern business environment is the importance of political as well as social factors. Change is only applicable and valid for a profit-making organization if it successfully rhymes with the social environment and political climate of the affected location. However, when the values of an organization tend to clash with the accepted cultural values in the target location, change becomes hard to implement. This is true for countries whose political and social structure is rigid to change. According to Sudibyo and Jianfu (2015), strategic change in an organization is significantly affected by the political structure that exists in the target location (p. 830). As such, expansion of organizational operations in companies with high rates of corruption such as China and Indonesia is bound to negatively affect the smooth running of the day to day business activities.

A country that exhibits negative political behaviour will affect a company's objective for growth through the creation of unnecessary challenges and barriers that are man-made. These challenges are bound to have strong political motivations which can only be solved by engaging in the culture of corruption. However, by engaging in such activities that may hurt the reputation of a company elsewhere, the company risks growing in a negative aspect which may hinder their potential for future growth. Therefore, strategic change aiming at growth in potentially negative locations needs to be done with much care to be able to manoeuvre through the political and cultural environment without really getting involved with the existing practices of the target location.

\section{Conclusion}

Strategic change is a complex process undertaken by organizations in the modern world. A process which has a lasting impact on the future success of the business operations of a given organization. However, by engaging proper resources in the strategic change initiative, companies are bound to successfully impact their capacity for growth. Nonetheless, their modern business environment contains a significant number of challenges which affect an organization's strategic change decisions in many ways. The challenges may arise from political, social as well as cultural issues. Consequently, most organizations have internal structural issues that might be the cause of their impending failure. As such, scholars have categorized strategic change to be amongst one of the most complex activities modern companies have to undertake to remain competitive in the ever-changing business environment. 


\section{References}

Bartunek, J.M., Woodman, R.W. (2015). Beyond Lewin: Toward a temporal approximation of organization development and change. Annual Review of Organizational Psychology and Organizational Behavior, 2, 157-182.

Bratnicka, K. (2015). Twórczość organizacyjna i efektywność organizacji w kierunku ujęcia wielopoziomowego. Problemy Zarządzania, 4 (56), 131-143.

Cummings, T., Nickerson, J.A. (2017). An Exploration of Brain Science and its Potential Contributions to Strategic Management \& Thinking. Academy of Management Proceedings, 1, 13144.

Ellis, K.M., Reus, T.H., Lamont, B.T., Ranft, A.L. (2011). Transfer effects in large acquisitions: How size-specific experience matters. Academy of Management Journal, 54 (6), 1261-1276.

Fan, G.H., Zietsma, C. (2017). Constructing ashared governance logic: The role of emotions in enabling dually embedded agency. Academy of Management Journal, 60 (6), 2321-2351.

Girod, S.J.G., Whittington, R. (2017). Reconfiguration, restructuring and firm performance: Dynamic capabilities and environmental dynamism. Strategic Management Journal, 38 (5), 1121-1133.

Graebner, M., Heimeriks, K., Huy, Q., Vaara, E. (2016). The process of post-merger integration: A review and agenda for future research. Academy of Management Annals, annals-2014.

Heimeriks, K.H., Schijven, M., Gates, S. (2012). Manifestations of higher-order routines: The underlying mechanisms of deliberate learning in the context of postacquisition integration. Academy of Management Journal, 55 (3), 703-726.

Klarner, P., Raisch, S. (2013). Move to the beat - Rhythms of change and firm performance. Academy of Management Journal, 56 (1), 160-184.

Kunisch, S., Bartunek, J., Mueller, J., Huy, Q. (2017). Time in Strategic Change Research. Academy of Management Annals.

Lee, B.H., Struben, J., Bingham, C.B. (2018). Collective action and market formation: An integrative framework. Strategic Management Journal, 39 (1), 242-266.

Menon, A. (2018). Bringing cognition into strategic interactions: Strategic mental models and open questions. Strategic Management Journal, 39 (1), 168-192.

Sudibyo, Y.A., Jianfu, S. (2015). Institutional theory for explaining corruption: An empirical study on public sector organizations in China and Indonesia. Corporate Ownership and Control, 13 (1), 817-958.

Vidal, E., Mitchell, W. (2018). Virtuous or vicious cycles? The role of divestitures as a complementary Penrose effect within resource-based theory. Strategic Management Journal, 39 (1), 131-154.

\section{STRATEGICZNA ZMIANA W PRZEDSIECBORSTWIE: ASPEKTY WIELOPLASZCZYZNOWE}

Streszczenie: Celem artykułu jest przegląd istniejącego zasobu wiedzy na temat zmiany strategicznej z perspektywy, która uwzględnia znaczenie czasu. Dlatego przegląd istniejącej literatury będzie zasadniczo oparty na różnych spojrzeniach. Po pierwsze, pojęcie czasu w strategicznej zmianie. Po drugie, czas i strategiczne działania zmian. Wreszcie, agenci czas i zmiany strategiczne. Perspektywy, na których skupi się ten artykuł, odnoszą się do związanych ze zmianą czasu elementów strategicznych zmian, które większość uczonych od dawna traktowała $z$ odmiennej perspektywy. Podejście wynikające z tego przeglądu odmienia aspekt spojrzenia na strategiczną zmianę pod względem dynamiki procesowej. W związku z tym artykuł skupi się na różnych postaciach strategicznych zmian, które dążą do osiągnięcia zamierzonego celu. Wartość merytoryczna i naukowa tego opracowania wyraża się w prezentacji tematu z nietypowego punktu widzenia, odnosząc się do konkretnego przekładu teorii na wnioski badawcze dotyczące zmiany strategicznej z punktu widzenia aspektów wielopłaszczyznowych. Oryginalne podejście różni się od dotychczas prezentowanych, w dużym stopniu wykorzystując najnowsze źródła literackie, biorąc pod uwagę złożoność zmian strategicznych, zintegrowanych z problemami firmy z perspektywy różnych aspektów w kontekście strategii korporacyjnej.

Słowa kluczowe: zmiana strategiczna, strategia przedsiębiorstwa, otoczenie biznesowe

\section{Citation}

Nowak, J. (2018). Strategic Change in a Firm: Multifarious aspects. Finanse, Rynki Finansowe, Ubezpieczenia, 2 (92), 373-379. DOI: 10.18276/frfu.2018.92-32. 